\author{
Arkadiusz Morawiec \\ Uniwersytet Łódzki \\ arkadiuszmorawiec@poczta.fm
}

\title{
Cyganki w Birkenau (w literaturze polskiej)
}

\section{Gypsy Women in Birkenau (in Polish Literature)}

\begin{abstract}
The article deals with the homicide on the Gypsy people perpetrated by the Nazi Germans during World War II and its representations in Polish literature (and, to a lesser extent, in Gypsy literature). The subject matter of the analysis is the motif of the Gypsy camp (Ziegeunerlager) functioning inside the Auschwitz-Birkenau Konzentrationslager, especially the image of Gypsy women inmates, shaped by both the camp reality and stereotypes, including the Orientalizing cliché about their particular sensuality.
\end{abstract}

Keywords: Polish literature, Gypsy literature, Gypsies, women, eroticism, homicide, Auschwitz-Birkenau, Ziegeunerlager (Gypsy camp)

Streszczenie: Artykuł dotyczy dokonanego przez Niemców w latach drugiej wojny światowej ludobójstwa Cyganów i jego reprezentacji w literaturze polskiej (w mniejszym stopniu - w literaturze cygańskiej). Przedmiotem analizy jest motyw obozu cygańskiego (Ziegeunerlager) funkcjonującego w obrębie Konzentrationslager Auschwitz-Birkenau, zwłaszcza wizerunek cygańskich kobiet, więźniarek, ukształtowany zarówno przez obozowe realia, jak i przez stereotypy, w tym orientalizującą kliszę, przypisującą Cygankom szczególną zmysłowość.

Słowa kluczowe: literatura polska, literatura cygańska, Cyganie, kobiety, erotyzm, ludobójstwo, Auschwitz-Birkenau, Ziegeunerlager (obóz cygański)

W opublikowanej niedawno monografii poświęconej wizerunkowi Cyganów w literaturze polskiej i rosyjskiej Anna Sobieska analizuje trzy kształtujące go mity: przestępczy, muzyczny i erotyczny. Zajmują ją - jak pisze - „trzy modele zniekształceń, wizji stereotypizujących, nierozłącznie związanych z obserwacją świata cygańskiego, naznaczających literackie świadectwa (...) od cza-

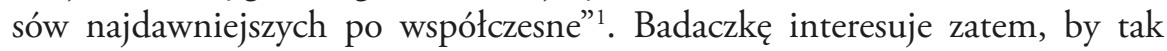

${ }^{1}$ A. Sobieska, Dzieci Hagar. Literackie wizerunki Romów/Cyganów. Studia imagologiczne, Warszawa 2015, s. 17. 
rzec, „barwność”, egzotyka Cyganów. Nie zajmuje natomiast, dokonana przez Niemców ich zagłada, w której należałoby może dostrzec zalążek kolejnego, czwartego, mitu, istotnego także dla samych Cyganów².

Pierwszy ze wspomnianych przez Sobieską mitów, przestępczy, w powiązaniu z tematem zagłady Cyganów często podlega wytłumieniu lub rewaloryzacji, widocznej na przykład w opowiadaniu Tadeusza Makarczyńskiego Cyganie wachtmeistra Schultza, w którym lekarstwem na burzących społeczny „ład i porządek” ${ }^{3}$ Cyganów jest ich doskonale zorganizowana przez Niemców eksterminacja, lub w Bitwie pod Grunwaldem Tadeusza Borowskiego, gdzie jeden z Polaków, były więzień funkcyjny, chwali się, że w obozie, dbając o swoich

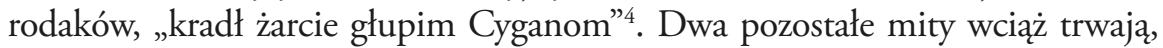
przy czym muzyczny nierzadko wciela się w motyw akompaniamentu egzekucji Cyganów, czego artystycznie znakomitym i przejmującym wyrazem jest zawarta w powieści Tadeusza Nowaka Takie większe wesele scena masowej zbrodni, której ostatni akord stanowi rozstrzelanie cygańskiej kapeli5. Najbardziej uporczywie, w kształcie najmniej naruszonym, trwa w literaturze polskiej - w kontekście zagłady Cyganów ${ }^{6}$, przez nich samych określanej mianem Porrajmos („Pożeranie”) lub Samudaripen („Masowy Mord”) - mit erotyczny. O nim jednak za chwilę.

Snując refleksję o cygańskiej pamięci zagłady, Lech Mróz stwierdził, że szeroko ujmowane dzieje Cyganów znane są jedynie z zapisów uczynionych przez nie-Cyganów, tak więc zarówno przeszłość, jak i opis oraz ocena ich kultury są ułomne, ogromnie uproszczone i płytkie ${ }^{7}$. Otóż opinia ta, gdyby potraktować ją literalnie i odnieść do Porrajmos, okazałaby się nieścisła. Dysponujemy bowiem w tym zakresie świadectwami także Cyganów, jakkolwiek są one, ze względu na „ciagłe upośledzenie edukacyjne” tej grupy, nieliczne i ograniczone głównie do niemieckiego obszaru językowego ${ }^{8}$. Dzięki Jerzemu

2 Słowo „Cyganie” uchodzi za niepoprawne politycznie. Używam go jednak z rozmysłem. Istnieją bowiem grupy Cyganów, wśród nich Sinti i Manusze, które nie identyfikują z politycznie poprawnym określeniem „Romowie”. Ponadto niektóre osoby z grupy Roma konsekwentnie określają siebie mianem Cyganów. Przede wszystkim jednak używanie słowa „Romowie” w kontekście realizowanej w czasie drugiej wojny światowej eksterminacji Cyganów fałszowałoby w pewien sposób przeszłość. Wprawdzie ofiarami nazistów byli niemal wyłącznie przedstawiciele dwóch grup: Roma i Sinti, jednak mordowano ich wówczas jako „Cyganów”.

3 T. Makarczyński, Cyganie wachtmeistra Schultza [w:] tegoż, Cyganie wachtmeistra Schultza, Warszawa 1977, s. 59.

${ }^{4}$ T. Borowski, Bitwa pod Grunwaldem [w:] tegoż, Pożegnanie z Maria. Opowiadania, Warszawa 1948 , s. 136.

5 T. Nowak, Takie większe wesele, Kraków 1966.

${ }^{6} \mathrm{Na}$ temat realizacji tematu zagłady Cyganów w literaturze polskiej i literaturze polskich Cyganów zob. A. Morawiec, Nie tylko Aświc. Zagtada Cyganów [w:] tegoż, Literatura polska wobec ludobójstwa. Rekonesans, Łódź 2018.

7 L. Mróz, Niepamięć nie jest zapominaniem. Cyganie-Romowie a Holokaust, „Przegląd Socjologiczny” 2000, z. 2, s. 110.

${ }_{8}$ Zob. J. Dębski, J. Talewicz-Kwiatkowska, Prześladowania i masowa zagłada Romów podczas II wojny światowej w świetle relacji i wspomnień, Warszawa 2007, s. 23. 
Ficowskiemu znamy także kilka wspomnień oraz pieśni wyrażonych w języku cygańskim, między innymi epicko ujęty wiersz Papuszy Krwawe tzy co za Niemców przeszliśmy na Wotyniu w 1943 i 44 roku i anonimowe pieśni cygańskie powstałe w Auschwitz-Birkenau.

Zarówno wspomnienia ${ }^{9}$, jak i Krwawe tzy $\ldots{ }^{10}$ zawierają cenne informacje na temat eksterminacji Cyganów dokonywanej w miejscu, gdzie ich ujęto (większość Cyganów zamieszkujących tereny okupowane przez Trzecią Rzeszę zginęła nie w obozach śmierci, lecz w zbiorowych egzekucjach), a anonimowe auszwickie pieśni bardziej indeksują niż odzwierciedlają rzeczywistość zagłady. Wynieśli je z Auschwitz - w pamięci - wysłani stąd do innych obozów Cyganie, ocaleńcy. Ficowski je tuż po wojnie zapisał, dokonał ich przekładu z języka cygańskiego na polski i opublikował ${ }^{11}$.

Aktualia i konkret są w nich reprezentowane skromnie - przez nieliczne nazwy własne, takie jak „Oświęcim” i „Niemcy”, oraz przez rzeczowniki: „obóz”, „bramy”, „komin”. W tych pieśniach-lamentach, będących głosem bólu i oskarżenia, powracają motywy uwięzienia, pracy ponad siły, bicia, rozłąki i tęsknoty za bliskimi (rodziną, ukochanym lub ukochana), marzenia o wolności, zwątpienia:
Wprowadzili nas przez bramy,
wypuszczają kominami.
Nie wyjdziemy już z obozu,
sióstr ni braci nie spotkamy ${ }^{12}$.

Znajdujemy w nich podobne, powtarzane frazy, widoczne już w incipitach: „Dom jest duży w Oświęcimiu...”, „Wielkie miasto ten Oświęcim...”, „Wielki obóz w Oświęcimiu...”, a także podobne motywy:

\section{(...) Lata mały ptaszek.}

Niechby zabrał słowa nasze,

może liścik mógłby zanieść

memu ojcu, mojej mamie...13;

9 Zawiera je książka J. Ficowskiego Cyganie polscy. Szkice historyczno-obyczajowe, Warszawa 1953 , s. $162-181$.

10 Papusza [właśc. B. Wajs], Krwawe tzy co za Niemców przeszliśmy na Wotyniu w 43 i 44 roku [w:] tejże, Pieśni Papuszy, tłum., oprac., wstęp, objaśnienia J. Ficowski, Wrocław 1956, s. 64-75.

11 J. Ficowski, Cyganie polscy..., dz. cyt., s. 107-109; obszerniejsza prezentacja: tenże, Cyganie na polskich drogach, wyd. 2 popr. i rozszerz., Kraków 1965, s. 215-219.

${ }_{12}$ [B. nazw.], ${ }^{* * *}$ [Wielki obóz w Oświęcimiu...], tłum. J. Ficowski [w:] J. Ficowski, Cyganie na polskich drogach, dz. cyt., s. 217.

13 [B. nazw.], *** [Dom jest duży w Oświęcimiu...], tłum. J. Ficowski [w:] J. Ficowski, Cyganie na polskich drogach, dz. cyt., s. 215. 
Liścik niesie czarny ptaszek,

liścik od rodziny naszej ${ }^{14}$;

Niechaj ptak, co w górze lata,

list przyniesie mi ze świata.

Niechby mi tu liścik przyniósł ${ }^{15}$.

Właściwie są to nie tyle odrębne pieśni, ile warianty ${ }^{16}$ auszwickiego archilamentu Cyganów.

W wypadku literatury powstałej w języku polskim, rozumianej szeroko, obejmującej oprócz utworów fikcjonalnych także tak zwaną literaturę dokumentu osobistego, pierwsze zapisy dotyczące prześladowań Cyganów - uwięzienia ich w gettach i obozach koncentracyjnych, eksterminacji w ośrodkach zagłady - pochodzą od nie-Cyganów: Polaków i polskich Żydów (względnie Polaków żydowskiego pochodzenia). Do najwcześniejszych należy opublikowana w 1944 roku w Warszawie konspiracyjna broszura Rok $w$ Treblince Jankiela Wiernika, uciekiniera z obozu zagłady (Treblinka II). Znajdujemy w niej wzmiankę o przybyłym do tego miejsca kaźni transporcie Cyganów z Besarabii:

brama otwiera się i wprowadzają około 100 Cyganów (był to już trzeci transport Cyganów) - około 200 mężczyzn, reszta kobiet[y] i dzieci. Za nimi na furmankach - cały ich dobytek. Brudne łachmany, porwana pościel i inne nędzne rzeczy. Przybyli oni prawie bez straży. Tylko dwaj Ukraińcy [sic!] w niemieckich mundurach prowadzili ich. (...) Cyganów jak wszystkich zagazowano i spalono ${ }^{17}$.

Inne świadectwo, wspomnienie polskiego Żyda Mieczysława Chodźki, byłego więźnia obozu karnego w Treblince (Treblinka I) ukazało się w tym samym roku, 6 września, na łamach organu PKWN „Rzeczpospolita”. Czytamy w nim między innymi:

Do folkloru w Polsce należały obozy cygańskie z ich romantyzmem i umiłowaniem życia koczowniczego. Stawały się często tematem utworów literackich, operetek, filmów itp.

14 [B. nazw.], *** [Wielkie miasto ten Oświęcim...], tłum. J. Ficowski [w:] J. Ficowski, Cyganie na polskich drogach, dz. cyt., s. 216.

15 [B. nazw.], *** [Wielki obóz w Oświęcimiu...], dz. cyt., s. 217.

16 Zob. J. Ficowski, Cyganie na polskich drogach, dz. cyt., s. 215; A. Bartosz, Nie bój się Cygana. Ne dara Romestar, wprow. L. Stomma, Sejny 2004, s. 246, przypis 2.

${ }^{17}$ [J. Wiernik], Rok w Treblince, Warszawa 1944, s. 19 (pisownia oryginalna). 
(...) Niemcy sprowadzali do „obozu pracy” w Treblince napotkanych Cyganów „ocyganionych” zapewnieniem, że będą żyli w specjalnie dla nich urządzonym obozie w lesie... (...) Do dołu zaganiano po 100 osób, do których strzelano z karabinów maszynowych ${ }^{18}$.

Do najwcześniejszych szeroko znanych publikacji odnoszących się do zagłady Cyganów należą, niepozbawione chwytów i walorów literackich, opublikowane w grudniu 1945 roku wspomnienia Seweryny Szmaglewskiej Dymy nad Birkenau. We wstępie do nich autorka wzmiankuje o Cyganach, których „potraktowano podobnie jak Żydów, zabierając [do gazu - A.M.] od razu cały obóz [cygański - A.M.], mieszczący mężczyzn, kobiety i dzieci”'19. W jednym z rozdziałów, zatytułowanym $N a$ wolność, autorka opisuje ten, ulokowany w Birkenau (Auschwitz II), obóz z perspektywy polskich więźniarek pracujących w kolumnie zbieraczek pokrzyw:

Oto (...) widać ludzi. Uderza widoczny poprzez druty brud i najzupełniejszy prymityw. Na ziemi, pokrytej plamami błotnych wybojów, mokrej nawet w dni pogodne, stoją baraki pełne szczelin i przewiewów. Spomiędzy nich wyzierają Cyganie, strojni w wielkie kapelusze, w buty z cholewami, ze śladami swej cygańskiej urody, zachowanymi w postaci kędzierzawych włosów, czarnych wąsików i fajeczek. Nie odebrano im niczego w czasie wchodzenia do obozu. Tuż obok jawią się ich kobiety w fałdziście bujnych spódnicach w kwiaty, w barwnych gorsetach opinających piersi, z rzędami korali i złotych monet nawleczonych na łańcuszki, z kolczykami podzwaniającymi z cicha w uszach. Są niezwykle brudne. Swoich adamaszkowych i jedwabnych szat nie zdejmują zapewne wieczorem, gdy kładą się spać przy mężach, nie myją ciemnych ciał, nie czeszą hebanowo czarnych włosów. Pośród nich biegają dzieci. Całkiem małe, półnagie, pod gęstwą czarnych kędziorów, lub większe, strojne jak ich rodzice. Cyganie - dzieci lasów i polnych dróg - naród bez ojczyzny ${ }^{20}$.

W rozdziale Cyklon Szmaglewska relacjonuje, w praesens historicum, likwidację tego obozu:

W kilka tygodni później obóz męski [w Birkenau - A.M.] zerwał się ze snu zbudzony krzykiem wielu tysięcy ludzi. Wystarczyło wyjść z baraków, żeby stwierdzić, co się dzieje. W jasno oświetlonym obozie cygańskim popędzani przez SS-manów wybiegają na drogę Cyganie, Cyganki i ich dzieci. Sformowani w piątki mają rozkaz wychodzić na drogę i iść do krematorium. Stawiają opór i stąd owe krzyki rozlegają się ponad Birkenau. Krzyki trwają całą noc, lecz na rano obóz cygański jest pusty ${ }^{21}$.

${ }_{18}$ M.Ch. [właśc. M. Chodźko], Cyganie w Treblince, „Rzeczpospolita” [Lublin] 1944, nr 35, s. 3.

19 S. Szmaglewska, Dymy nad Birkenau, Warszawa 1945, s. 7.

20 Tamże, s. 137.

${ }^{21}$ Tamże, s. 236-237. 
Perspektywa narracyjna Szmaglewskiej, w której Cyganie - mężczyźni, kobiety i dzieci - są ujmowani łącznie, jako grupa, jest uzasadniona tym, że w ramach kompleksu Birkenau uwięziono ich w przeznaczonym specjalnie dla nich sektorze (obozie) rodzinnym, Zigeunerlager (określanym również jako Ziegeunerfamilienlager). Obserwowani z dystansu, poprzez druty, stanowili jedność. Opowiadając o losie Cyganów w Birkenau, trudno więc zarówno autorom wspomnień, jak i literaturoznawcy wydestylować los cygańskich kobiet jako wyraziście odrębny, wyrazić go w oderwaniu od losu mężczyzn i dzieci. Pozwolę więc sobie, skupiając się na losie Cyganek, nie zarzucać tej ogólnej perspektywy, pomimo że - jak zdaje się wynikać z przeprowadzonego przeze mnie rekonesansu - w wypadku licznych utworów literatury polskiej, zwłaszcza autorstwa mężczyzn, spośród Cyganów najlepiej widoczne są kobiety.

Przywołany wcześniej, poświęcony cygańskiej pamięci, artykuł Lecha Mroza rozpoczyna się cytatem ze „wspomnień Borowskiego z Oświęcimia”:

- (...) Albo jest wigilia, albo niema [sic!], a ty śpisz! Hej, muzykanty, grać, taka wasza mać!

Przez otwarte drzwi uderzył jazgotliwy pisk cygańskiej kapeli. Dwie młode cyganki przewiązane barwnymi chustami u ramion poczęły tańczyć u progu, potrząsając nad głową rękami ustrojonymi w bransolety ${ }^{22}$.

Badacz opatruje go następującym komentarzem:

Zwykle, jeśli pojawia się we wspomnieniach wątek obozu cygańskiego [w Birkenau A.M.], autorzy podkreślają jego barwność, dźwięki muzyki, jakie dobiegały stamtąd, gwar i - co może jeszcze bardziej fascynowało w samotności osób skazanych na to wielkie ludzkie zbiorowisko - pozór normalności, jaki nosił w sobie obóz rodzinny ${ }^{23}$.

Tylko ci, przekonuje Mróz, którzy ze względu na wykonywane funkcje mieli bezpośrednią styczność z Cyganami lub widzieli ich prowadzonych do komór gazowych, dostrzegali w nich przede wszystkim współwięźniów, umęczonych, cierpiących ludzi. Pełniejszy obraz ich tragicznego losu, na który złożyły się: głód, choroby, śmierć bliskich i okrutne eksperymenty medyczne, dali jednak przede wszystkim - stwierdza badacz - nieliczni ocaleni z Auschwitz Cyganie: „W ich wspomnieniach (...) nie znajdujemy kolorowych chustek, furkoczących spódnic i brzęku bransolet, nie ma skrzypiec ani muzyki, jest cierpienie, rozpacz i czasami próby oporu czy ucieczki”24.

${ }^{22}$ L. Mróz, dz. cyt., s. 89.

23 Tamże.

${ }^{24}$ Tamże, s. 90. Autor odsyła czytelnika do złożonych przez Cyganów świadectw, zawartych w drugim tomie publikacji Ksiega pamięci. Cyganie w obozie koncentracyjnym Auschwitz-Birkenau, red. J. Parcer, München 1993, s. 1491-1540. 
Wydaje się jednak, że Mróz ujmuje rzecz zbyt radykalnie. Tragedię Cyganów, ich cierpienie, dostrzegali, i to wyránie, także nie-Cyganie. O ich próbie oporu wspomina, jak widzieliśmy, Szmaglewska. Poza tym trudno traktować obraz zawarty w zacytowanym „wspomnieniu” Borowskiego, a ściślej, w łączącym cechy dokumentu i literatury opowiadaniu Ogień krzepnie... ${ }^{25}$, jako emblematyczny dla postrzegania Cyganów w Birkenau przez innych więźniów. Zbiorowym bohaterem tego utworu są wszakże więźniowie funkcyjni („elita”), głównie Polacy, doskonale radzący sobie w obozie, prowadzący ciemne interesy z esesmanami, dysponujący nadmiarem jedzenia i alkoholu oraz... kobietami. Jest to opowieść o więźniach zlagrowanych, wyzutych ze współczucia dla tych, którzy znaleźli się na dnie ${ }^{26}$. Ironiczny kontrapunkt dla tego (głównego) motywu opowiadania stanowi wieńcząca je scena prominenckiej Wigilii, podczas której „wszyscy [są - A.M.] dobrzy i kochani, nikt się nie łajdaczy i nie kradnie" ${ }^{27}$. Odbywa się ona w sali porodowej szpitala (w obozie cygańskim), za której drzwiami - narrator wyraźnie to eksponuje - nadzy i wychudli chorzy dopominają się o chleb. Inna rzecz, że Cyganie, których władze KL Auschwitz nie „przebrały” w pasiaki, którym nie ścięły włosów i nie odebrały bagaży, w tym instrumentów muzycznych $^{28}$, byli postrzegani - trudno, aby było inaczej - jako barwna osobliwość. Taki obraz zgodny był z wciąż żywotnym stereotypem, ukształtowanym, począwszy od romantyzmu, w znacznym stopniu przez literaturę i sztukę $e^{29}$.

Co istotne, z utworem Borowskiego, zarówno wymieniającym wśród „prominencji” blokową Italianę, Cygankęę, jak i ukazującym Cyganów „obdartych i brudnych" oraz boso człapiące po śniegu „głodne dzieci cygańskie"31,

25 Pochodzi ono z tomu J. Nel Siedleckiego, K. Olszewskiego i T. Borowskiego Byliśmy w Oświęcimiu, Monachium 1946. Borowski napisał je „według opowiadania Siedleckiego” - zob. T. Mikulski, $Z$ marginesów twórczości Tadeusza Borowskiego, „Pamiętnik Literacki” 1954, z. 4, s. 591.

${ }^{26}$ „ZLAGROWANY - człowiek, który myśli tylko kategoriami życia obozowego i postępuje wg moralności obozowej” (Określenia oświęcimskie [w:] J. Nel Siedlecki, K. Olszewski, T. Borowski, dz. cyt., s. 208).

${ }^{27}$ [T. Borowski], Ogień krzepnie... [w:] J. Nel Siedlecki, K. Olszewski, T. Borowski, dz. cyt., s. 128.

${ }^{28}$ Zob. „Sytuacja Cyganów w obozie rodzinnym była początkowo nieco lepsza od położenia pozostałych więźniów KL Auschwitz. Przede wszystkim wszyscy - mężczyźni, kobiety i dzieci - przebywali razem. Nosili cywilną odzież, pozostawiono im przywieziony dobytek, pieniądze, przedmioty wartościowe, nie ścinano włosów, nie byli zmuszani do ciężkiej, morderczej pracy. Część z nich była zatrudniona jedynie wewnątrz obozu cygańskiego" (H. Kubica, Dzieci i mtodzież w KL Auschwitz [w:] Auschwitz 1940-1945. Węztowe zagadnienia z dziejów obozu, red. W. Długoborski, F. Piper, Oświęcim-Brzezinka 1995, t. 2, s. 187).

${ }^{29}$ Zob. „A przecież świat Romów jest inny. Jest światem barwnym, wirującym, radosnym” (J. Malicki, Postscriptum [w:] I. Kwiek, Na goraco, Katowice 2010, s. 91). Autor tej wypowiedzi jest profesorem filologii polskiej, Izolda Kwiek - romską poetką.

${ }^{30}$ Italianą, komplementując w ten sposób jej urodę, nazywano w Birkenau niemiecką Cygankę Petermann - zob. J. Ficowski, Cyganie polscy..., dz. cyt., s. 177; K. Smoleń, Cyganie w KL Auschwitz-Birkenau [w:] Los Cyganów w KL Auschwitz-Birkenau. Das Schicksal der Sinti und Roma im KL Auschwitz-Birkenau, red. J. Parcer, Oświęcim 1994, s. 123.

31 [T. Borowski], Ogień krzepnie..., dz. cyt., s. 121-122. 
korespondują wspomnienia Wiesława Kielara zatytułowane Anus mundi. Kielar, były więzień KL Auschwitz, zapewnia, że wiedział o wszystkim, co dzieje się „u Cyganów”, gdyż bywał w obozie rodzinnym ${ }^{32}$. W jego relacji mają oni zdarte już ubrania, jakkolwiek - powiada autor:

widziało się też i dobrze odzianych Cyganów i Cyganki, szczególnie te młode i urodziwe. One nie potrzebowały przychodzić pod druty naszego obozu [tj. sąsiadującego z obozem cygańskim szpitala - A.M.] i prosić o kawałek chleba czy papierosa. Siedziały w pokojach blokowych - buduarach, gdzie grała muzyka, dziewczęta tańczyły, wóda się lała, kwitła wolna miłość. Zacierały się różnice rasowe w trakcie orgii i pijaństw, w których uczestniczyła cała śmietanka, a więc funkcyjni obozu cygańskiego, ba, nawet esesmani ${ }^{33}$.

W ostatnim akapicie rozdziału poświęconego Cyganom Kielar wspomina o buchającym z kominów krematoryjnych wysokim płomieniu i dymie. Widzi zatem i barwy, i śmierć.

Przywołane wcześniej fragmenty Dymów nad Birkenau świadczą o tym, że również Szmaglewska, dostrzegając noszących wielkie kapelusze Cyganów, odziane w spódnice w kwiaty Cyganki i równie strojne dzieci, jest świadoma tragicznego losu tych - jak pisze - ludzi. Próżno natomiast szukać barwnego obrazu Cyganów we wspomnieniach Krystyny Żywulskiej. W Przeżytam Oświęcim eksponuje ona ich śmierć. W rozdziale Cyganie wspomina o likwidacji Zigeunerlager: „kilka tysięcy poszło w nocy »do gazu“”34. W dalszym fragmencie książki notuje: „Tej pamiętnej nocy 1 sierpnia 1944 roku spalono wszystkich pozostałych Cyganów z województwa białostockiego i z Niemiec, i małych Cyganów, którzy bawili się w palenie Żydów, i smukłe śniade Cyganki, czarnookie, zwinne, żywe" ${ }^{35}$. Warto jeszcze nadmienić, że w pamięci Arnolda Mostowicza, który odwiedził obóz cygański w łódzkim getcie, zachował się całkowicie „bezbarwny” obraz dna dna: „Nadchodzące do getta wieści o warunkach, w jakich żyli Cyganie (wieści nieoddające zresztą przerażającej prawdy), poprawiały samopoczucie zamkniętych w getcie [Żydów - A.M.]. Oto nie oni znajdują się na dnie. Na dnie poniżenia, nędzy, głodu"36. Często jednak bywa tak, że cudze cierpienie uświadamiamy sobie dopiero wtedy - wypada tutaj zgodzić się z Lechem Mrozem - gdy sami zaczynamy odczuwać ból.

W ostatnich latach historycy poświęcają zagładzie Cyganów coraz więcej uwagi, analizując różnego rodzaju dokumenty, w tym zapisy słowne. Zbrodnia ta znalazła odzwierciedlenie nie tylko w literaturze świadectwa.

32 W. Kielar, Anus mundi. Wspomnienia oświęcimskie, Kraków 1972, s. 299.

33 Tamże, s. 298-299.

${ }^{34}$ K. Żywulska [właśc. S. Landau], Przeżytam Oświęcim, Warszawa 1946, s. 172.

35 Tamże, s. 215. Notabene Cyganów z Białegostoku zagazowano wcześniej, 23 marca 1943 roku.

36 A. Mostowicz, Żótta gwiazda i czerwony krzyż, Warszawa 1988, s. 27. 
Temat dokonanej w Auschwitz eksterminacji Cyganów doszedł do głosu również w literaturze sensu stricto fikcjonalnej.

Do najważniejszych w tym zakresie utworów należą dwa wiersze promotora wiedzy o Cyganach i o ich zagładzie, Jerzego Ficowskiego. Mam na myśli dobrze znaną Modlitwę do świętej wszy z tomu Śmierć jednorożca z $1981 \mathrm{roku}^{37}$, o której parę słów za chwilę, i znacznie wcześniejszą, pochodzącą z lat czterdziestych, Śpiewkę o cygańskiej śmierci z debiutanckiego zbioru Otowiani żotnierze $e^{38}$, wcale jednak niebędąca, wbrew tytułowi, śpiewką. Cygańska śpiewka, traktująca o rozstaniu kochanków, odejściu, pojawia się w nim jako cytat. Włączając tę „smutną piosenkę" w zasadniczy tok wypowiedzi, Ficowski nadaje jej, poprzez zmianę adresu, odmienny od pierwotnego charakter. Otóż wersy:

Kiedy pójdę sobie,

co zostawię tobie?

Zostawię ci, zostawię

moje wierne słowo ${ }^{39}$,

w kontekście, w którym przywołane są popioły, ogień i Oświęcim, i „dusze dziewcząt spalone przed świtem" ${ }^{\prime 40}$, tracą cechy erotyku, przemieniając się w uwewnętrzniony przez poetę i realizowany przezeń w utworze, a ściślej, poprzez tekst, nakaz utrwalenia (utrwalania) w słowie niedawnej tragedii: „odejścia” Cyganów. Ich śmierć w komorach gazowych Auschwitz upamiętnia także, wspomniana już, należąca do najlepiej znanych utworów literatury polskiej podejmujących temat zagłady Cyganów, Modlitwa do świętej wszy. Genezę tego znakomitego wiersza Ficowski przedstawia następująco:

Co niedziela na terenie obozu cygańskiego przeprowadzano tzw. Läusekontrolle sprawdzano, czy więźniowie są zawszeni. Odwszanie prowadzono kolejno, blokami. Ubrania zabierano do dezynfekcji, Cyganów pędzono do kąpieli. Nieodebrane Cyganom ubrania cywilne zniszczyły się i przydzielono im trochę obozowych łachów pozostałych po zmarłych. Włosy ostrzyżono dopiero w marcu lub kwietniu 1944 roku. Pewnego razu, w czasie odwszania bloku, Niemiec, pilnujący Cyganek w kąpieli, spostrzegł, że kąpiąca się Cyganka trzyma coś w zaciśniętej garści. Przypuszczając, że to złoto, kazał jej otworzyć pięść. Okazało się, że Cyganka ukrywała w dłoni wszy, chcąc je uchronić od zagłady. Wytłumaczyła potem, że zrobiła to, aby jej sprzyjał dobry los. „Bo kiedy wesz odejdzie od człowieka - to śmierć” ${ }^{\prime 1}$.

${ }^{37}$ J. Ficowski, Modlitwa do świętej wszy [w:] tegoż, Śmierć jednorożca, Warszawa 1981, s. $82-84$.

38 Tenże, Śpiewka o cygańskiej śmierci [w:] tegoż, Otowiani żotnierze, Warszawa 1948, s. 24-26.

39 Tamże, s. 24.

40 Tamże.

${ }^{41}$ J. Ficowski, Cyganie polscy..., dz. cyt., s. 177. 
Modlitwę do świętej wszy wieńczą słowa:
Została pusta dłoń
i niebo puste
I wchodził w nie
za dymem dym
za dymem dym ${ }^{42}$.

Poeta przemienił więc smutną anegdotę $\mathrm{w}$ równie smutną, niemal bluźnierczą, pieśń o pustym niebie. Ukrywająca w dłoni już nie trywialną wesz, lecz „nasienie ucieczki”, Cyganka - obsadzona przez „odkrywcę” Papuszy w roli podmiotu mówiącego - śpiewa w „łaźni birkenau” o tym, że „bóg w piekle nie bywa”. Jego miejsce, w jej pieśni, w Birkenau zajmuje... wesz: „ocal mnie/ święta wszy”. Jeżeli Bóg nie jest władny ocalić człowieka, to przynajmniej człowiek, w tym przypadku kobieta, może ocalić wesz, „ziarnko życia”.

Wspominałem wcześniej o relacjach dotyczących zagłady Cyganów opublikowanych już w czasie wojny. Oprócz nich, ale też obok utworów „zaglądających” do Zigeunerlager, można umieścić swoiście dokumentujący (i indeksujący) tę zbrodnię wiersz Tadeusza Hołuja Przybycie Cyganów, powstały, jak informuje umieszczona pod nim notka, w lipcu 1944 roku w obozie w Oświęcimiu ${ }^{43}$. Swoistość tego specyficznego dokumentu wynika nie tylko z jego wierszowanej formy, lecz także stąd, że ma on - co chyba przestaje nas już dziwić - znamiona erotyku. Obozowe realia są w nim dyskretne: lager to zaledwie "nasze miasto”, zamiast „esesmana” pojawia się tutaj, idący z gorzałką, „rudy Niemiec”. O prawdziwym, groźnym obliczu „miasta” w sposób wyrazistszy świadczą „czerwony blok” i pusta prycza po zmarłym przyjacielu; łagodzą je - „kapele w blokach” i „cygański smyczek" ${ }^{44}$. W wypowiedzi podmiotu znajduje wyraz, współgrające z pożądaniem i podsycane przez nie, pragnienie wolności, radości, powrotu tam, gdzie „rzeka, powietrze i las”. Źródłem pożądania jest sytuacja analogiczna do tej, o której wspominają przywołane wcześniej teksty Borowskiego i Kielara, przy czym Hołuj wyraża ją w sposób mniej dosadny, rzec by można, że - poprzez ubranie jej w metafory - swoiście skłamany:

${ }^{42}$ Tenże, Modlitwa do świętej wszy, dz. cyt., s. 84.

43 T. Hołuj, Przybycie Cyganów [w:] tegoż, Wiersze z obozu, Warszawa 1946, s. 52-53.

${ }^{44} \mathrm{Te}$ i inne zawarte w wierszu realia zdają się odnosić do obozu macierzystego (Auschwitz I), w którym więziony był Hołuj (zob. tegoż, Ciag dalszy. Szkice o przygodach utworów, Kraków 1980, s. 42-43). Jednak motywy cygańskie, w tym zwłaszcza tytuł wiersza i wzmianka o Cygankach, nie wykluczają, że w wierszu mowa jest o Birkenau (bowiem to przede wszystkim tutaj więziono Cyganów, a w szczególności Cyganki). 
Głodne cyganki nocą tną druty mosiądz skóry oddając za chleb, brzuchy basów, gdy milczą - ucisz, nakarm, napój i bierz ${ }^{45}$.

Znamieniem tyleż realiów Birkenau, ile wcieleniem stereotypu przypisującego Cygankom szczególną pożądliwość ${ }^{46}$, jest również opublikowana w 1964 roku Stacja ptonącej nocy Jana Marii Gisgesa, byłego więźnia Auschwitz ${ }^{47}$. Ten wywiedziony z doświadczenia utwór ma znamiona opowiadania literackiego. Jego ramę narracyjną wyznacza wspomnienie odbytej niedawno przez narratora-bohatera wycieczki do oświęcimskiego muzeum, a konkretnie do Brzezinki. Odwiedziny te wywołują odleglejsze wspomnienie zdarzeń sprzed lat dwudziestu. W utworze splatają się dwa wątki. Pierwszy, zasadniczy, dotyczy współwięźnia, którego bohater odwodzi od samobójstwa. Impulsem do podjęcia tego desperackiego kroku jest, obserwowana przez obu więźniów, likwidacja obozu cygańskiego. Drugi wątek, wywiedziony z pierwszego poprzez (kolejna) retrospekcję, dotyczy młodej, pięknej Cyganki, która przed wojną wywróżyła bohaterowi długie życie. Dziewczyna, ponownie spotkana przezeń w obozie, świadoma nadchodzącej śmierci, oddaje mu się. Wkrótce bohater widzi ją po raz ostatni. Właściwie nie tyle ją widzi, ile domyśla się jej obecności w gronie wyselekcjonowanych do przedśmiertnego upokorzenia dziewcząt:

Poprzez okna zamarłej cygańskiej kuchni w łunie widziałem kobiety z trudem włażące do samochodów, za nimi inne ciągnęły za rączki dzieci płaczące w głos, jeszcze inne tuliły do piersi nagie niemowlęta, które pomimo nocy jaśniały widoczne z naszego oddalenia. Dookoła popychającego się, idącego posłusznie tłumu stali w szerokim rozkroku żołnierze. Niektórzy z nich wyłuskiwali z pomieszanych piątek młode dziewczyny. Już kilka zbiło się w gromadkę obok tłoczącej się nagiej kolumny. Zanim zginą, jeszcze tej nocy przejdą przez piekło żołdackiego masowego gwałtu ${ }^{48}$.

W wieńczącej opowiadanie refleksji narratora pojawia się wątpliwość, czy postąpił słusznie, uwalniając przyjaciela „od tego, co zdawało mu się, że jest jego ratunkiem”" ${ }^{49}$, oraz mało pocieszająca go pewność, iż uratował cy-

45 T. Hołuj, Przybycie Cyganów, dz. cyt., s. 52.

46 Por. A. Sobieska, dz. cyt., s. 267-270. Dość szczególnym wcieleniem tego stereotypu (na który w tym wypadku nakłada się stereotyp Cyganki-wiedźmy) jest stara, „chuda jak szkielet, czarna jak diabel” polska Cyganka z opowiadania M. Zarębińskiej-Broniewskiej Entlausung - odwszenie, przyłączająca się w łaźni Birkenau do „cynicznego, bezwstydnego tańca” niemieckich więźniarek, które zgłosiły się do pufu, obozowego burdelu (w: tejże, Opowiadania oświęcimskie, Warszawa 1948, s. 23-24).

47 J.M. Gisges, Stacja ptonącej nocy [w:] tegoż, Brudne śniegi, Warszawa 1964, s. 5-48.

48 Tamże, s. 22.

49 Tamże, s. 47. 
gańską dziewczynę przed niepamięcią. Powiada: „ta kruchość pamięci o niej ze mną przepadnie" 50 . Oczywiście trwać będzie ona dopóty, dopóki będziemy czytać Stację ptonacej nocy.

Podobnych zabiegów, utworów ocalających pamięć o zagładzie Cyganów, dokonanej między innymi w Auschwitz-Birkenau, znajdujemy w literaturze polskiej więcej. Są wśród nich, obok już wspomnianych, Mariana Pankowskiego Smagta swoboda ${ }^{51}$, Tadeusza Nowaka Psalm betlejemski ${ }^{52}$, Jarosława Iwaszkiewicza Cyganie $^{53}$, a także utwory adresowane do młodzieży i dzieci: Dzieciństwo w pasiakach Bogdana Bartnikowskiego z 1969 roku $^{54}$, zawierające osnuty wokół likwidacji Zigeunerlager rozdział Cygańskie dzieci, oraz opublikowana w 2013 roku książka obrazkowa Mietek na wojnie z tekstem Natalii Gancarz i ilustracjami Diany Karpowicz ${ }^{55}$, stanowiąca śmiały projekt przybliżenia młodemu czytelnikowi rzeczywistości obozu zagłady widzianej oczami dziecka, polskiego Cygana.

Do najbardziej znanych i najważniejszych dzieł literatury polskiej poświęconych zagładzie Cyganów (w Auschwitz i gdzie indziej) należy opublikowany w 2011 roku reportaż Lidii Ostałowskiej Farby wodne $e^{56}$, nominowany rok później do Nagrody Literackiej „Nike”, co bez wątpienia wzmogło jego poczytność. Książka ta ważna jest już choćby dlatego, że w formie quasi-literackiej, a więc percypowanej przez szerszy krąg odbiorców niż wypowiedzi naukowe, ujmuje najważniejsze fakty dotyczące eksterminacji Cyganów.

Autorka wprowadza je w związku z głównym wątkiem opowieści, dotyczącym czeskiej Żydówki Diny Gottliebovej i wykonanych przez nią w Birkenau, na zlecenie SS-Hauptsturmführera Josefa Mengelego, akwarelowych portretów Cyganów i Cyganek. Stanowiąc przedmiot głośnego w pierwszej dekadzie XXI wieku sporu między ich autorką a Państwowym Muzeum Auschwitz-Birkenau, wizerunki te są przede wszystkim jednym z nielicznych śladów Porrajmos; portretowani Cyganie byli ofiarami badań naukowych niesławnego doktora. Ostałowska na marginesie opowieści o Gottliebovej i zagładzie Żydów wspomina o niemieckich ustawach antycygańskich, przesiedleniach i deportacjach Cyganów do gett i obozów, o ich mordowaniu „w lasach” i w Auschwitz (ten przypadek został potraktowany szerzej), a także o żmudnych zabiegach Cyganów, aby świat wreszcie dostrzegł ich tragedię, oraz o wykorzystywaniu przez nich pamięci zagłady do budowania własnej (romskiej) tożsamości narodowej. Reportażystka opowiada w sposób zajmujący, artystycznie udany i kompetentny. Czytelnik, który zna publikacje wymienione w zamykającej Farby wodne bibliografii, musi docenić faktograficzną rzetelność

50 Tamże.

51 M. Pankowski, Smagta swoboda, Paris 1955.

52 T. Nowak, Psalm betlejemski [w:] tegoż, Psalmy, Kraków 1971, s. 17.

53 J. Iwaszkiewicz, Cyganie [w:] tegoż, Kragty rok. Cykl wierszy, Warszawa 1967, s. 23.

54 B. Bartnikowski, Dzieciństwo w pasiakach, Warszawa 1969.

55 N. Gancarz, Mietek na wojnie, il. D. Karpowicz, Tarnów 2013.

56 L. Ostałowska, Farby wodne, Wołowiec 2011, s. 78. 
autorki. Ostałowska w książce nie tylko korzysta z opracowań naukowych, ale także cytuje między innymi Borowskiego i Rudolfa Hössa oraz Tadeusza Joachimowskiego, który, pełniąc w obozie cygańskim funkcję pisarza (schreibera), wraz z dwoma współwięźniami ukrył w ziemi w lipcu 1944 roku dokument niezwykłej wagi: księgi ewidencyjne Cyganów.

„Cyganie - czytamy w Farbach wodnych - są w obozie nieobecni, zostały po nich niewyraźne ślady, zazwyczaj w cudzych wspomnieniach. I księgi wydobyte z ziemi przez szrajbera Tadeusza Joachimowskiego. Czas to zmienić" ${ }^{7}$. $\mathrm{Z}$ pewnością należy to zmienić. Przede wszystkim najwyższy czas przyjrzeć się bliżej, wnikliwiej i krytycznie znanym nam doskonale wojennym i obozowym (zwłaszcza postauszwickim) narracjom i wydobyć z nich wątki cygańskie, tak jak nauczyliśmy się wyodrębniać z nich wątki żydowskie (na przykład z opowiadań Borowskiego czy z Dymów nad Birkenau). Jak się okazuje, literatura polska uczestniczy w upamiętnianiu zagłady Cyganów „od zarania”.

Oczywiście los cygańskich mężczyzn, kobiet i dzieci w Birkenau ma oprócz wymiaru tragicznego również wymiar genderowy. Jego bodaj najbardziej dobitnym przejawem w literaturze polskiej, zwłaszcza w utworach napisanych przez mężczyzn, jest uparte trwanie, odwołującego się do orientalizujących klisz, stereotypu przypisującego Cygankom szczególną zmysłowość, zgoła rozwiązłośćs ${ }^{8}$. Tymczasem stawką w erotycznej grze, rzeczywiście uprawianej przez niektóre Cyganki w cieniu krematoriów, ujmowanej przez niecygańskich więźniów poprzez utrwalone kulturowo wyobrażenia i pobudzane przez nie (erotyczne) fantazje, było najczęściej ratowanie życia, własnego i najbliższych. Kobiece ciało bywało, zwłaszcza w późniejszym okresie funkcjonowania Zigeunerlager, ostatnim towarem, który można było wymienić na chleb.

W każdym razie sami Cyganie, w ostatnich latach coraz konsekwentniej utrwalający pamięć o Porrajmos, pełniącą istotną funkcję w kształtowaniu ich tożsamości ${ }^{59}$, obywają się bez akcentowania płci ofiar, współsióstr i współbraci. Nic w tym dziwnego, gdyż zarówno „w lasach”, jak i w obozach Cyganie ginęli zwykle jako rodziny, jako tabory. Odzwierciedleniem tego jest nie tylko inskrypcja na zbiorowej (wielorodzinnej) mogile w Szczurowej i tablica informacyjna obok Pomnika Pamięci o Zagładzie Romów w Borzęcinie ${ }^{60}$, lecz także rozwijająca się od niedawna polskojęzyczna poezja Cyganów, między innymi Karola Parno Gierlińskiego z grupy Sinti i Izoldy Kwiek z grupy Roma, eksponująca wspólnotowość cygańskiego cierpienia ${ }^{61}$. Jest to jednak temat na osobny artykuł...

57 Tamże, s. 210.

58 Zob. A. Sobieska, dz. cyt., s. 268.

59 Zob. S. Kapralski, Naród z popiotów. Pamięć zagtady a tożsamość Romów, Warszawa 2012.

${ }^{60}$ Notabene Cyganie ze Szczurowej wiedli osiadły tryb życia.

${ }^{61}$ Zob. np. K.P. Gierliński, Meteory, Szczecinek 2007; I. Kwiek, Żal, Kraków 1995. 


\section{Bibliografia}

Bartnikowski B., Dzieciństwo w pasiakach, Warszawa 1969.

Bartosz A., Nie bój się Cygana. Ne dara Romestar, wprow. L. Stomma, Sejny 2004.

Borowski T., Bitwa pod Grunwaldem [w:] tegoż, Pożegnanie z Marią. Opowiadania, Warszawa 1948.

Dębski J., Talewicz-Kwiatkowska J., Prześladowania i masowa zagtada Romów podczas II wojny światowej w świetle relacji i wspomnień, Warszawa 2007.

Ficowski J., Cyganie na polskich drogach, wyd. 2 popr. i rozszerz., Kraków 1965.

Ficowski J., Cyganie polscy. Szkice historyczno-obyczajowe, Warszawa 1953.

Ficowski J., Modlitwa do świętej wszy [w:] tegoż, Śmierć jednorożca, Warszawa 1981.

Ficowski J., Śpiewka o cygańskiej śmierci [w:] tegoż, Otowiani żotnierze, Warszawa 1948.

Gancarz N., Mietek na wojnie, il. D. Karpowicz, Tarnów 2013.

Gierliński K.P., Meteory, Szczecinek 2007.

Gisges J.M., Stacja ptonącej nocy [w:] tegoż, Brudne śniegi, Warszawa 1964.

Hołuj T., Ciag dalszy. Szkice o przygodach utworów, Kraków 1980.

Hołuj T., Przybycie Cyganów [w:] tegoż, Wiersze z obozu, Łódź 1945.

Iwaszkiewicz J., Cyganie [w:] tegoż, Kragty rok. Cykl wierszy, Warszawa 1967.

Kapralski S., Naród z popiołów. Pamięć zagtady a tożsamość Romów, Warszawa 2012. Kielar W., Anus mundi. Wspomnienia oświęcimskie, Kraków 1972.

Ksiega pamięci. Cyganie w obozie koncentracyjnym Auschwitz-Birkenau, red. J. Parcer, München 1993, t. 2.

Kubica H., Dzieci i mtodzież w KL Auschwitz [w:] Auschwitz 1940-1945. Węztowe zagadnienia z dziejów obozu, t. 2, red. W. Długoborski, F. Piper, Oświęcim 1995.

Kwiek I., Żal, Kraków 1995.

M.Ch. [właśc. M. Chodźko], Cyganie w Treblince, „Rzeczpospolita” [Lublin] 1944, nr 35.

Makarczyński T., Cyganie wachtmeistra Schultza [w:] tegoż, Cyganie wachtmeistra Schultza, Warszawa 1977.

Malicki J., Postscriptum [w:] I. Kwiek, Na goraco, Katowice 2010.

Mikulski T., $Z$ marginesów twórczości Tadeusza Borowskiego, „Pamiętnik Literacki” 1954, z. 4.

Morawiec A., Nie tylko Aświc. Zagtada Cyganów [w:] tegoż, Literatura polska wobec ludobójstwa. Rekonesans, Łódź 2018.

Mostowicz A., Żótta gwiazda i czerwony krzyż, Warszawa 1988.

Mróz L., Niepamięć nie jest zapominaniem. Cyganie-Romowie a Holokaust, „Przegląd Socjologiczny" 2000, z. 2.

Nel Siedlecki J., Olszewski K., Borowski T., Byliśmy w Oświęcimiu, Monachium 1946.

Nowak T., Psalm betlejemski [w:] tegoż, Psalmy, Kraków 1971.

Nowak T., Takie większe wesele, Kraków 1966.

Ostałowska L., Farby wodne, Wołowiec 2011.

Pankowski M., Smagta swoboda, Paris 1955. 
Papusza [właśc. B. Wajs], Krwawe tzy co za Niemców przeszliśmy na Wotyniu w 43 i 44 roku [w:] tejże, Pieśni Papuszy, tłum., oprac., wstęp, objaśnienia J. Ficowski, Wrocław 1956.

Smoleń K., Cyganie w KL Auschwitz-Birkenau [w:] Los Cyganów w KL Auschwitz-Birkenau. Das Schicksal der Sinti und Roma im KL Auschwitz-Birkenau, red. J. Parcer, Oświęcim 1994.

Sobieska A., Dzieci Hagar. Literackie wizerunki Romów/Cyganów. Studia imagologiczne, Warszawa 2015.

Szmaglewska S., Dymy nad Birkenau, Warszawa 1945.

[Wiernik J.], Rok w Treblince, Warszawa 1944.

Zarębińska-Broniewska M., Entlausung - odwszenie [w:] tejże, Opowiadania oświęcimskie, Warszawa 1948.

Żywulska K. [właśc. S. Landau], Przeżytam Oświęcim, Warszawa 1946. 